\title{
MALARIA MORBIDITY PREDICTION SCENARIO IN INDONESIA
}

\author{
Tria Anggita Hafsari, Yulinda Nurul Aini, Fuat Edi Kurniawan \\ Research Center for Population \\ Indonesian Institute of Sciences, Jakarta, Indonesia \\ Corresponding Author Email: triaanggitaoı@gmail.com
}

\begin{abstract}
WHO declared that Indonesia is a country at risk of malaria, because of the high rates of malaria morbidity. Government commitment in eradicating malaria has been realized in Malaria elimination program. The program aims to reduce Malaria case to zero in 2030. Starting from 20II, Indonesia suffered a drop in API's value from $\mathrm{I} .75$ to $0.84 \%$. Despite the numerous drop in Malaria cases, some regions are until now suffering from large major outbreaks especially in the eastern Indonesia. The aim of this paper is to predict the trend of malaria morbidity with the API variable value of each targeted area in Indonesia. The prediction method employed in this research was deterministic method using extrapolation trends and probabilistic method using ARIMA (Autoregressive Integrated Moving Average) using variation percentage of training and testing data to obtain the best prediction method. Result of this article was API value scenario in Indonesia up to 2030 for every targeted area. Based on the analysis result, the best method to predict the value of API was exponential growth method since it had the smallest MAPE value, which was 38.48 using $80 \%$ training data and $20 \%$ testing data. Prediction results indicated that the first targeted area had eliminated malaria in 2016, the second targeted area target would eliminated malaria in 2019 and the third targeted area was by 2022 . Whereas the fourth targeted area covers Papua, West Papua, East Nusa Tenggara, Maluku and North Maluku had not eliminated malaria until 2030.
\end{abstract}

Keywords : ARIMA, extrapolation trend, malaria, morbidity, prediction

\section{Abstrak}

WHO menyatakan bahwa Indonesia merupakan negara yang berisiko malaria, karena tingginya angka kesakitan malaria. Komitmen pemerintah dalam memberantas malaria telah diwujudkan dalam program eliminasi malaria. Program ini bertujuan untuk mengurangi kasus Malaria menjadi nol pada tahun 2030. Sejak tahun 20II, Indonesia mengalami penurunan nilai API dari I,75 menjadi 0,84\%. Meskipun terjadi banyak penurunan, beberapa daerah masih memiliki jumlah kasus malaria yang tinggi, terutama di Indonesia bagian timur. Tujuan dari makalah ini adalah untuk memprediksi tren morbiditas malaria dengan nilai variabel API dari setiap target area di Indonesia. Metode prediksi yang digunakan dalam penelitian ini adalah metode deterministik menggunakan tren ekstrapolasi dan mtode probabilistik menggunakan ARIMA (Autoregressive Integrated Moving Average) menggunakan variasi persentase data pelatihan dan pengujian untuk mendapatkan metode prediksi terbaik. Hasil dari artikel ini adalah skenario nilai API di Indonesia hingga 2030 untuk setiap target area. Berdasarkan hasil analisis, metode terbaik untuk memprediksi nilai API adalah metode pertumbuhan eksponensial karena memiliki nilai MAPE terkecil, yaitu 38,48 menggunakan data pelatihan $80 \%$ dan data pengujian $20 \%$. Hasil prediksi menunjukkan bahwa target area pertama sudah tereliminasi malaria di tahun 20I6, target area ke-2 akan tereliminasi malaria di tahun 
2019 dan target area ke-3 di tahun 2022. Sedangkan target area ke-4 yang meliputi wilayah Papua, Papua Barat, NTT, Maluku, dan Maluku Utara belum Ioo\% tereliminasi malaria hingga tahun 2030.

Kata kunci: ARIMA, extrapolation trend, malaria, morbiditas, prediksi

\section{INTRODUCTION}

Malaria has become a global issue which is one of the national health priorities in Indonesia nevertheless. At the global level, achieving the Sustainable Development Goals (SDGs) malaria elimination program is one of the targets to be achieved on the topic of Good Health and Wellbeing. Malaria is a type of infectious disease caused by the parasite Plasmodium Sp which multiplies in the body of the Anopheles Sp. then transmitted to humans bites. Generally parasites that cause malaria reproduce in tropical places (Darundiati, 2003). Malaria can cause death and endemic globally since malaria is categorized as an Extraordinary Event (KLB).

Serious commitment to complete malaria elimination in the health sector could be seen from the issuance of Minister of Health Decree No. 293 of 2009 concerning the Malaria Elimination Policy. In this policy, malaria is confirmed as a problem which until now is still a concentration of the national government to be alleviated. The programs launched by the government to achieve malaria elimination include blood tests with ACT (Artemisinin based-Combination Therapy), distribution of bed nets, socialization of the danger of malaria, etc. This was encouraged to eradicate malaria prevalence in all regions of Indonesia and maintained areas that have been free of malaria.

API (Annual Parasite Incidence) is an indicator to determine the development of the spread of malaria in a region. The API value is defined as the number of malaria positive cases per Iooo inhabitants in one year. This indicator is useful for showing trends in malaria morbidity and determining whether malaria endemicity still occurs in an area. The number of positive malaria cases in 2010 was 465,764 cases with an API value of 1.96\%. This value is the highest number from the period 2009-20I0. Indonesia has experienced the peak of the malaria outbreak in 2006 with an API value of $28.74 \%$. Therefore, Indonesia free of malaria is one of the promises of President Joko Widodo. Although since 2oro the API value had continued to experience a decline, there were yet many regions where the number of malaria cases falls into the high category, especially in the eastern part of Indonesia (Hanandita and Tampubolon, 2016). Therefore, WHO (2012) stated that Indonesia is one of the countries at risk of malaria, given Indonesia's climate and geographical conditions support for the proliferation of parasites that cause malaria.

In Indonesia, malaria elimination programs were carried out in four stages, namely (I) eradication, (2) pre-elimination, (3) elimination, and (4) maintenance. This malaria elimination program targeted Indonesia to be free of malaria by 2030. The targeted areas for malaria elimination programs were carried out in stages because the variety of malaria cases in Indonesia was varied. The following is a malaria endemicity map in Indonesia. 
Figure I. Malaria Endemicity in Indonesia, 2016

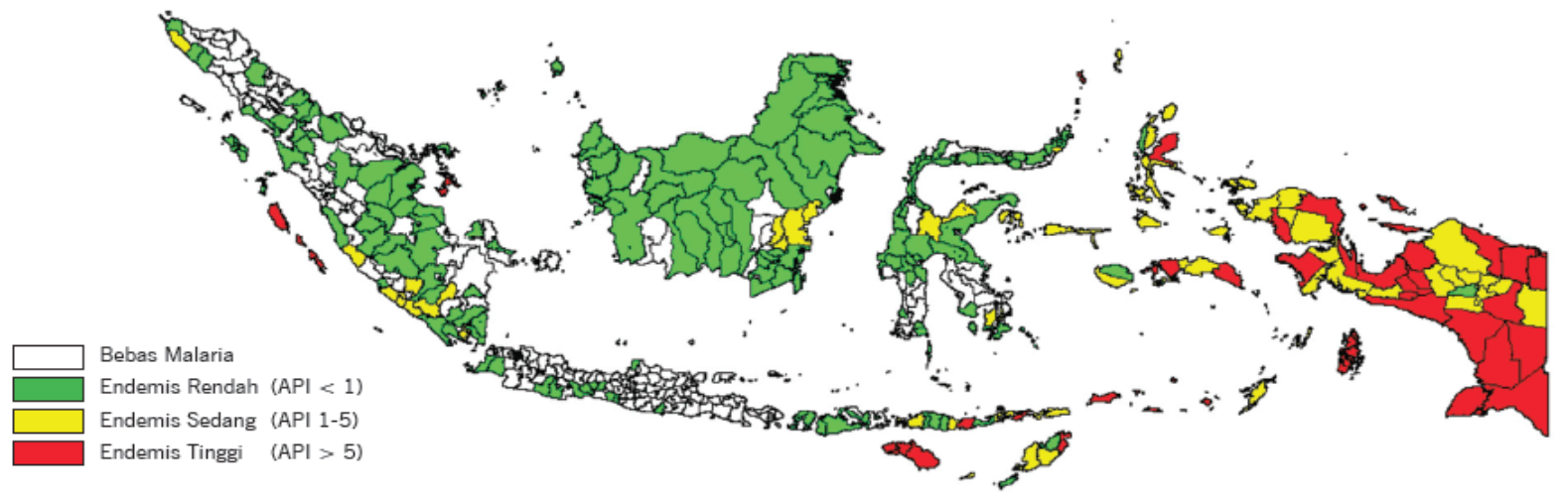

Source : Center of data and information Indonesia's ministry of health, 2017

Some studies related to malaria morbidity included research by Sutarto \& Eka (20I7) who have analyzed environmental factors, health services, and community behavior towards the spread of Malaria. The results have shown that these three factors have been utmost important in malaria control. Another study was conducted by Sopi \& Patanduk (2015) regarding malaria in children under the age of five. This research has shown the importance of health education to the community regarding the impact of malaria on children through playing methods along with mentoring by parents. Rejeki, et al (2014) in their research on Malaria API in Banyumas Regency has shown that the factors influencing the API value have been the area, number of migrants, and population density. Research on the prevalence of clinical malaria and positive Plasmodium based on the mass blood survey in Riau Province's Rokan Hilir Regency was conducted by Abidin \& Hernawan (2010). The study has shown that plasmodium parasites have been found in people who have had clinical symptoms of malaria (fever) and in the childern o-9 years. The next research was conducted by Rachmadhani \& Widayani (20I4) regarding malaria susceptibility prediction modeling using the Ordinary Least Square (OLS) method in a part of Kulon Progo Regency. The results have shown that malaria susceptibility prediction models have shown an increase and decrease in incidence based on environmental physical parameters.
Previous studies related to malaria more discussed about the factors that influence malaria, methods of prevention and control of malaria, prevalence of clinical malaria in the population, and prediction of malaria susceptibility. There have been no studies discussing the predictions of malaria morbidity in order to support the malaria elimination program planned by the Ministry of Health. In addition, in making predictions, previous research used more deterministic methods, such as OLS, whereas OLS was a rigid method since many assumptions must be tested.

The aim of this study is to provide predictions of malaria morbidity for each target area through illustration of the achievement of malaria elimination in 2030. This prediction can be the basis for monitoring and evaluating malaria elimination programs in Indonesia, hence the government and related parties can determine the right strategies to reach Program Indonesia Malaria Free 2030. Research limitations in this paper were (I) the data used were API data from 2004-20I6, (2) the prediction methods used were probabilistic method using ARIMA and deterministic method using extrapolation trends, (3) distribution of training data and testing used a certain percentage, (4) determination the best scenario model used MAPE values (Mean Absolute Percentage Error) and MSE values (Mean Square Error), (5) predictions only made for each target area. 


\section{RESEARCH METHODOLOGY}

\section{Data and Data Source}

The data used in this research was secondary data which was determined using Annual Parasite Incidence (API) values per year, from 2000-20I6. API is the number of malaria positive cases per Iooo population in a year, thus the API data type is numerical with a ratio scale. API data was obtained from the Directorate General of Disease Prevention and Control, the Ministry of Health of Indonesia.

\section{Technique of Data Analysis}

Data processing techniques for making malaria morbidity prediction scenarios in Indonesia used probabilistic and deterministic methods. Forecast for probabilistic methods would use ARIMA (Autoregressive Integrated Moving Average) model, while forecast for deterministic methods would use Extrapolation Trends with different percentages of data usage and model types. ARIMA is a forecasting technique that ignores the independent variables in forming forecast. This method used only the present and historical values of independent variables to forecast. While the extrapolation trend method was a method which observe the level and type of data changes in the past as predictive substance. The following is the description about the forecasting scenarios of malaria morbidity.

Table I. Forecasting Scenario of Malaria Morbidity

\begin{tabular}{|c|c|c|c|c|}
\hline \multirow{2}{*}{$\begin{array}{l}\text { Sce- } \\
\text { nario }\end{array}$} & \multicolumn{2}{|c|}{ Data Sharing } & \multirow{2}{*}{$\begin{array}{l}\text { Forecasting } \\
\text { Method }\end{array}$} & \multirow{2}{*}{ Model Type } \\
\hline & Training & Testing & & \\
\hline \multirow{5}{*}{1} & \multirow{5}{*}{$70 \%$} & \multirow{5}{*}{$30 \%$} & ARIMA & $\begin{array}{l}\text { Different } \\
\text { orde of } p, d \text {, } \\
\text { and } q\end{array}$ \\
\hline & & & \multirow{4}{*}{$\begin{array}{l}\text { Extrapola- } \\
\text { tion Trend }\end{array}$} & Linear \\
\hline & & & & Quadratic \\
\hline & & & & $\begin{array}{l}\text { Exponential } \\
\text { Growth }\end{array}$ \\
\hline & & & & S-curve \\
\hline \multirow{5}{*}{2} & \multirow{5}{*}{$80 \%$} & \multirow{5}{*}{$20 \%$} & ARIMA & $\begin{array}{l}\text { Different } \\
\text { orde of } p, d \text {, } \\
\text { and } q\end{array}$ \\
\hline & & & \multirow{4}{*}{$\begin{array}{l}\text { Extrapola- } \\
\text { tion Trend }\end{array}$} & Linear \\
\hline & & & & Quadratic \\
\hline & & & & $\begin{array}{l}\text { Exponential } \\
\text { Growth }\end{array}$ \\
\hline & & & & S-curve \\
\hline
\end{tabular}

\begin{tabular}{|c|c|c|c|c|}
\hline \multirow{2}{*}{$\begin{array}{l}\text { Sce- } \\
\text { nario }\end{array}$} & \multicolumn{2}{|c|}{ Data Sharing } & \multirow{2}{*}{$\begin{array}{l}\text { Forecasting } \\
\text { Method }\end{array}$} & \multirow{2}{*}{ Model Type } \\
\hline & Training & Testing & & \\
\hline \multirow{5}{*}{3} & \multirow{5}{*}{$90 \%$} & \multirow{5}{*}{$10 \%$} & ARIMA & $\begin{array}{l}\text { Different } \\
\text { orde of } p, d \text {, } \\
\text { and } q\end{array}$ \\
\hline & & & \multirow{4}{*}{$\begin{array}{l}\text { Extrapola- } \\
\text { tion Trend }\end{array}$} & Linear \\
\hline & & & & Quadratic \\
\hline & & & & $\begin{array}{l}\text { Exponential } \\
\text { Growth }\end{array}$ \\
\hline & & & & S-curve \\
\hline
\end{tabular}

The analysis steps for predicting malaria morbidity are as follows:

I) Dividing data into training and testing data, with percentage of $70 \%-30 \%, 80 \%$ $-20 \%$, and $90 \%-10 \%$.

2) Identifying forecasting models using ARIMA method for each percentage of training data by observing the ACF (Auto Correlation Function) and PACF (Partial Auto Correlation Function) plots to determine significant lags and the presence/absence of seasonal periods. After the model has been obtained, parameter significance test and residual assumption test are performed which include white noise test and normality test.

3) Identifying forecasting models using extrapolation trend for each percentage of training data and model types, namely linear, quadratic, exponential growth, and s-curve. Furthermore, parameter significance testing will be performed for each model types.

4) Testing the goodness of model using the smallest MSE (Mean Square Error) value. This value is obtained by comparing testing data and forecasting results in each forecast method.

5) Making predictions of malaria morbidity in Indonesia year 2019-2030 using the best forecasting model for each targeted area.

\section{RESULT AND DISCUSSION}

\section{Annual Parasite Incidence (API) Description}

The malaria elimination program was a follow-up of global commitments on malaria 
elimination at the WHA $60^{\text {th }}$ meeting on 18 May 2007. Indonesia was one of the highlights due it was included in the list of countries at risk of malaria. In 2006, malaria cases in Indonesia were the highest cases in the past decade. 2,II6,066 malaria cases were counted in that year. Based on this global commitment in 2009, the Ministry of Health issued a Decree containing policies and strategies regarding malaria elimination. The latest malaria situation in 2016 showed that the number of patients suffering malaria was 200,378 people (Ministry of Health, 20I6).

The malaria elimination program which was initiated in 2009 prioritized regional strategies in controlling malaria, therefore the main thing in the program besides the technical implementation of the program was to stratify areas that had high API values. This was as a consequence in 2007 , which this year was nonetheless set by the API as an indicator of the development of the spread of malaria, there were 396 out of a total of 495 districts / cities in Indonesia that were declared malaria endemic (Hermiatie and Rukmini, 20I2). Thus, the target area of the malaria elimination program was also carried out in stages according to the endemic level, namely:

I) Thousand Islands (DKI Jakarta), Bali Island, and Batam (2010)

2) Java Island, Nanggroe Aceh Darussalam (NAD) Province and Riau Islands (2015)

3) Sumatra Island (except NAD Province and Riau Islands), West Nusa Tenggara Province,

4) Kalimantan Island and Sulawesi (2020)
5) Papua, West Papua, East Nusa Tenggara, Maluku and North Maluku Provinces (2030)

The sequence of the target areas for the malaria elimination program was determined through the results of identification of malaria stratification in 2007.

The initial stage in this analysis was the identification of API values pattern based on malaria prevalence cases in Indonesia from 2004-2016 using descriptive statistics. Based on Figure 2, the API value tends to increase from 2004-2007, where there were I9-29 people from Iooo populations who were positively infected with malaria. However, the API value had decreased quite dramatically in 2007 with an average of 3 out of Iooo residents who were malaria positive. This was in line with the commencement of malaria prevention efforts given the incidence of malaria in 2006 which resulted in deaths of up to 120,000 people (The conversation). In the following years, the API value tended to decrease with a value close to o, until in 2017 the API value is 0.77 or there was I in Iooo residents who are malaria positive in Indonesia. Furthermore, areas with a high level of malaria infection were West Papua, Papua, East Nusa Tenggara, Maluku, and North Maluku. The 5 areas were located in eastern Indonesia and were the target area for malaria elimination. In 2007, the eastern part of Indonesia was detected as the region with the highest spread of parasites plasmodium sp. this was indicated by the geographical conditions of the eastern part of Indonesia which has the potential for malaria parasites to breed.

Figure 2. API Trends In 2004-2016

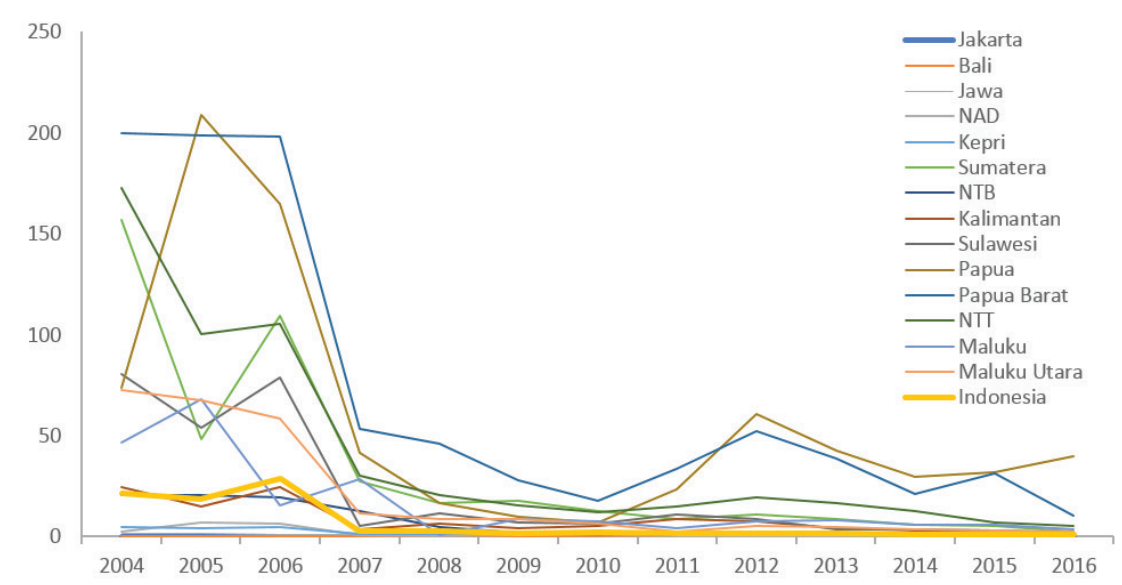


From Figure 2, it can be seen that the data on API values in 2004-2016 did not form a specific pattern and did not have a seasonal pattern, as a result malaria cases did not occur with certain patterns. Seeing the absence of certain patterns that experience repetition, preparedness and anticipation were needed to avoid malaria resurgence in areas that have been free of malaria. One of the efforts of the regional government to overcome the occurrence of resurgence was by implementing a treatment program with ACT, distributing bed nets, especially in malaria endemic areas, migration surveillance, and several other programs. In addition to focuse on eliminating malaria in areas with high API values, the absence of malaria resurgence in endemic areas that had been free of malaria had become an equally important focus, for instance in the Kulon Progo Regency area. The pattern of the API value graph was the basis for forecasting the API value from 2019 until 2030.

\section{API Value Predicting Using ARIMA and Ex- trapolation Trend Model}

\section{ARIMA Model}

The first stages in ARIMA model was identifying the order of $\operatorname{ARIMA}(\mathrm{p}, \mathrm{d}, \mathrm{q})$ by doing the stationary test of mean and variance. The results of Augmented Dickey Fuller test produced p-value 0.004 consequently the data was said to be stationary in mean. Then, Box-Cox Transformation test showed that the data had been stationary in variance with rounded value I. Since the data is stationary, the order $\mathrm{d}$ for ARIMA wass o.

Data which had been stationary in mean and variance was used to identify the ARIMA model by observing the ACF and PACF plots for each percentage of training data. The following were the ACF and PACF plots which are formed.

Figure 3. Plot ACF and PACF (a) Training Data 70\% (b) Training Data $80 \%$ (c) Training Data 90\% (a)

\begin{tabular}{|c|c|c|c|c|c|c|c|c|c|}
\hline \multicolumn{3}{|c|}{ Autocorrelation } & \multicolumn{3}{|c|}{ Partial Correlation } & \multirow{2}{*}{$\begin{array}{l}A C \\
0.561\end{array}$} & \multirow{2}{*}{$\begin{array}{c}\text { PAC } \\
0.561\end{array}$} & \multirow{2}{*}{$\begin{array}{l}\text { Q-Stat } \\
4.8084\end{array}$} & \multirow{2}{*}{$\begin{array}{c}\text { Prob } \\
0.028\end{array}$} \\
\hline 1 & & 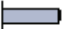 & 1 & & 1 & & & & \\
\hline 1 & & 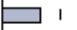 & 1 & 1 & 2 & 0.379 & 0.094 & 7.2212 & 0.027 \\
\hline 1 & & 曰 & - & 1 & 3 & 0.163 & -0.121 & 7.7192 & 0.052 \\
\hline 1 & c & I & 무 & 1 & 4 & -0.072 & -0.222 & 7.8295 & 0.098 \\
\hline I & $\square$ & 1 & - & 1 & 5 & -0.210 & -0.124 & 8.8900 & 0.114 \\
\hline 1 & 8 & 1 & 1 & 1 & 6 & -0.198 & 0.065 & 9.9898 & 0.125 \\
\hline 1 & $\square$ & I & $\square$ & 1 & 7 & -0.350 & -0.260 & 14.096 & 0.050 \\
\hline 1 & $\square$ & 1 & 1 & 1 & 8 & -0.282 & -0.009 & 17.425 & 0.026 \\
\hline 1 & ㅁ & 1 & 1 & 1 & 9 & -0.221 & -0.008 & 20.151 & 0.017 \\
\hline 1 & 口 & 1 & 1 & 1 & 10 & -0.183 & -0.058 & 22.957 & 0.011 \\
\hline 1 & c & 1 & 1 & 1 & 11 & -0.088 & -0.017 & 24.258 & 0.012 \\
\hline
\end{tabular}

(b)

\begin{tabular}{|c|c|c|c|c|c|c|c|c|c|c|}
\hline \multicolumn{3}{|c|}{ Autocorrelation } & \multicolumn{3}{|c|}{ Partial Correlation } & \multicolumn{2}{|r|}{$\mathrm{AC}$} & PAC & Q-Stat & Prob \\
\hline 1 & 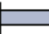 & & 1 & & & 1 & 0.636 & 0.636 & 6.9614 & 0.008 \\
\hline 1 & 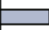 & & 1 & b & 1 & 2 & 0.483 & 0.133 & 11.316 & 0.003 \\
\hline 1 & $\square$ & 1 & 1 & 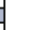 & 1 & 3 & 0.310 & -0.069 & 13.279 & 0.004 \\
\hline 1 & 它 & 1 & 1 & & 1 & 4 & 0.115 & -0.168 & 13.574 & 0.009 \\
\hline 1 & & 1 & 1 & & 1 & 5 & -0.005 & -0.063 & 13.575 & 0.019 \\
\hline 므 & & I & $1 \sqsubset$ & & 1 & 6 & -0.206 & -0.237 & 14.762 & 0.022 \\
\hline$\square$ & & 1 & $1 \square$ & & 1 & 7 & -0.471 & -0.416 & 21.860 & 0.003 \\
\hline $1 \square$ & & 1 & 1 & $\square$ & 1 & 8 & -0.359 & 0.275 & 26.673 & 0.001 \\
\hline $1 \square$ & & 1 & 1 & b & 1 & 9 & -0.319 & 0.133 & 31.232 & 0.000 \\
\hline $1 \square$ & & 1 & 1 & $y$ & 1 & 10 & -0.253 & -0.041 & 34.822 & 0.000 \\
\hline 1 믄 & & 1 & 1 & 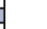 & 1 & 11 & -0.196 & -0.113 & 37.693 & 0.000 \\
\hline 미 & & 1 & 1 & | & 1 & 12 & -0.158 & -0.010 & 40.475 & 0.000 \\
\hline
\end{tabular}

(c)

\begin{tabular}{|c|c|c|c|c|c|c|c|c|c|}
\hline \multicolumn{2}{|c|}{ Autocorrelation } & \multicolumn{3}{|c|}{ Partial Correlation } & \multirow{2}{*}{\multicolumn{2}{|c|}{$\frac{A C}{0.692}$}} & \multirow{2}{*}{$\begin{array}{l}\text { PAC } \\
0.692\end{array}$} & \multirow{2}{*}{$\begin{array}{c}\text { Q-Stat } \\
9.6781\end{array}$} & \multirow{2}{*}{$\begin{array}{c}\text { Prob } \\
0.002\end{array}$} \\
\hline 1 & $\square$ & 1 & & $\square$ & & & & & \\
\hline 1 & $\square$ & 1 & 马 & 1 & 2 & 0.558 & 0.151 & 16.380 & 0.000 \\
\hline 1 & ים & 1 & & 1 & 3 & 0.414 & -0.036 & 20.332 & 0.000 \\
\hline 1 & $\sqsupseteq$ ～ & 1 & & 1 & 4 & 0.248 & -0.134 & 21.863 & 0.000 \\
\hline 1 & b 1 & 1 & & 1 & 5 & 0.146 & -0.024 & 22.438 & 0.000 \\
\hline 1 & 1 & 15 & & 1 & 6 & -0.023 & -0.188 & 22.454 & 0.001 \\
\hline $1 \square$ & I & $1 \square$ & & 1 & 7 & -0.259 & -0.350 & 24.615 & 0.001 \\
\hline $1 \square$ & 1 & 1 & & 1 & 8 & -0.315 & 0.019 & 28.168 & 0.000 \\
\hline $1 \square$ & I & 1 & & 1 & 9 & -0.364 & 0.022 & 33.505 & 0.000 \\
\hline$\square$ & 1 & 1 & 4 & 1 & 10 & -0.408 & -0.094 & 41.169 & 0.000 \\
\hline 10 & 1 & 1 & b & 1 & 11 & -0.316 & 0.149 & 46.532 & 0.000 \\
\hline$\square$ & 1 & 1 & 5 & I & 12 & -0.277 & 0.070 & 51.492 & 0.000 \\
\hline
\end{tabular}

ACF and PACF plots were used to determine the tentative ARIMA model (p, d, q). Based on Figure 2, tentative model of ARIMA was obtained for each percent of training data. ACF and PACF plot for $70 \%$ training data showed the ARIMA order $\mathrm{p}=\mathrm{I}$ and $\mathrm{q}=\mathrm{I}$, hence the model used was ARIMA $(\mathrm{I}, \mathrm{O}, \mathrm{O})$, ARIMA $(\mathrm{O}, \mathrm{O}, \mathrm{I})$, and ARIMA (I,O,I). ACF and PACF plot for $80 \%$ training data showed ARIMA $\mathrm{p}=\mathrm{I}$ and $\mathrm{q}=\mathrm{I}$ order, therefore tentative models were ARIMA $(\mathrm{I}, \mathrm{O}, \mathrm{O})$, ARIMA (o,o,I), and ARIMA (I,O,I) . For 90\% training data, the ACF and PACF plots showed the order $\mathrm{p}=\mathrm{I}$ and $\mathrm{q}=2$, so that the tentative model was ARIMA (2,O,I), ARIMA (I,O,2), and ARIMA (I,O,I ) The following were the test results which included parameter significance test, white noise test and residual normality test for each tentative training data model. 
Table 2. ARIMA Models

\begin{tabular}{|c|c|c|c|c|c|c|c|}
\hline \multirow[b]{2}{*}{ Training Data } & \multirow[b]{2}{*}{ Model } & \multicolumn{3}{|c|}{ Parameter Significance Test } & \multicolumn{3}{|c|}{ Assumptions Test } \\
\hline & & Parameter & Value & Conclusion & $\begin{array}{l}\text { White } \\
\text { Noise }\end{array}$ & Normality & Conclusion \\
\hline \multirow{4}{*}{$70 \%$} & $(1,0,0)$ & $A R(1)$ & 0 & Significant & 0 & 0,026 & Fulfilled \\
\hline & $(0,0,1)$ & $\mathrm{MA}(1)$ & 0,016 & Significant & 0 & 0,073 & Fulfilled \\
\hline & \multirow{2}{*}{$(1,0,1)$} & $A R(1)$ & 0 & Signifikan & \multirow{2}{*}{0} & \multirow{2}{*}{0,133} & \multirow{2}{*}{ Not Fulfilled } \\
\hline & & $\mathrm{MA}(1)$ & 0,258 & Not Significant & & & \\
\hline \multirow{4}{*}{$80 \%$} & $(1,0,0)$ & $A R(1)$ & 0 & Significant & 0.949 & 0.001 & Fulfilled \\
\hline & $(0,0,1)$ & $\mathrm{MA}(1)$ & 0,008 & Significant & 0,228 & 0.150 & Not Fulfilled \\
\hline & \multirow{2}{*}{$(1,0,1)$} & $A R(1)$ & 0 & Significant & \multirow{2}{*}{0,995} & \multirow{2}{*}{0,05} & \multirow{2}{*}{ Fulfilled } \\
\hline & & $\mathrm{MA}(1)$ & 0,214 & Not Significant & & & \\
\hline \multirow{8}{*}{$90 \%$} & \multirow{3}{*}{$(2,0,1)$} & $A R(2)$ & 0,98 & Not Significant & \multirow{3}{*}{0,978} & \multirow{3}{*}{0,01} & \multirow{3}{*}{ Fulfilled } \\
\hline & & $A R(1)$ & 0,214 & Not Significant & & & \\
\hline & & $\mathrm{MA}(1)$ & 0,642 & Not Significant & & & \\
\hline & \multirow{3}{*}{$(1,0,2)$} & $\mathrm{AR}(1)$ & 0 & Significant & \multirow{3}{*}{0,982} & \multirow{3}{*}{0,01} & \multirow{3}{*}{ Fulfilled } \\
\hline & & $\mathrm{MA}(2)$ & 0,734 & Not Significant & & & \\
\hline & & $\mathrm{MA}(1)$ & 0,173 & Not Significant & & & \\
\hline & \multirow{2}{*}{$(1,0,1)$} & $\mathrm{AR}(1)$ & 0 & Significant & \multirow{2}{*}{0,989} & \multirow{2}{*}{0,01} & \multirow{2}{*}{ Fulfilled } \\
\hline & & $\mathrm{MA}(1)$ & 0,164 & Not Significant & & & \\
\hline
\end{tabular}

Table 2 shows that there are several models which have insignificant parameters and does not fulfilled one of the residual assumption tests. Therefore, to determine the best model from ARIMA probabilistic method, the MSE value was used. The model with the smallest MSE value is the best ARIMA tentative model.

Table 3 Goodness of fit ARIMA model

\begin{tabular}{lll}
\hline Training Data & Model & MSE \\
\hline \multirow{2}{*}{$70 \%$} & $(1,0,0)$ & 70,239 \\
& $(0,0,1)$ & 158,050 \\
& $(1,0,1)$ & 71,523 \\
\hline \multirow{2}{*}{$80 \%$} & $(1,0,0)$ & 59,434 \\
& $(0,0,1)$ & 134,550 \\
\hline \multirow{2}{*}{$90 \%$} & $(1,0,1)$ & 59,618 \\
\hline
\end{tabular}

Table 3 shows that the tentative model with the smallest MSE value is the ARIMA model (I,O,I) with 90\% training data. Although the model has one parameter that was not significant, the model has fufilled the white noise test and residual normality test, therefore the best model in probabilistic method was ARIMA (I,O,I) model.

\section{Extrapolation Trend Model}

Extrapolation trends were deterministic methods in forecasting which have several types of models, namely linear, quadratic, exponential growth, and s-curve which were adjusted to the data pattern. The extrapolation trend method was used because the data pattern in Figure I shows that the API value data tended to form a downward trend from 2004-2016. The following was the identification result of extrapolation trend model for every model types followed by goodness of fit result using MSE value.

Table 4. Goodness of fit Test for Extrapolation Trend Method

\begin{tabular}{lll}
\hline Training Data & Model & MSE \\
\hline \multirow{3}{*}{$70 \%$} & Linear & 35,5693 \\
& Quadratic & 31,6062 \\
& Exponential Growth & 85,03 \\
& S-curve & 50,1944 \\
\hline \multirow{3}{*}{$80 \%$} & Linear & 31,969 \\
& Quadratic & 31,844 \\
& Exponential Growth & 64,207 \\
& S-curve & 384,197 \\
\hline \multirow{3}{*}{$90 \%$} & Linear & 30,421 \\
& Quadratic & 47,5289 \\
& Exponential Growth & 28,456 \\
& S-curve & 318,804 \\
\hline
\end{tabular}


Based on Table 4, on the previous page, it can be seen that the extrapolation trend model with the smallest MSE value (28.456) is an exponential growth model with the use of $90 \%$ training data, thus the model was the best deterministic model. The exponential growth equation obtained was as follows.

$$
A P I_{t}=44,717 \cdot\left(0,7752^{t}\right)
$$

\section{Prediction of API Value 2019-2030}

From several prediction scenarios for malaria morbidity as measured by API values using both probabilistic and deterministic forecasting methods, the best model for each method was obtained. The following was a comparison of MSE values from both methods.
Table 5. Comparison of Deterministic and Probabilistic Methods

\begin{tabular}{llll}
\hline Method & $\begin{array}{l}\text { Training } \\
\text { Data }\end{array}$ & Model & MSE \\
\hline Deterministic & $90 \%$ & $\begin{array}{l}\text { Exponential } \\
\text { Growth }\end{array}$ & 28,456 \\
Probabilistic & $90 \%$ & ARIMA $(1,0,1)$ & 47,721 \\
\hline
\end{tabular}

Based on Table 5, it can be seen that the best method for predicting API values is the deterministic method uzsing an exponential growth model with $90 \%$ training data. Therefore, the prediction of API values would be carried out using an exponential growth model with the following results.

Figure 4. API Value Forecast for The First Targeted Area

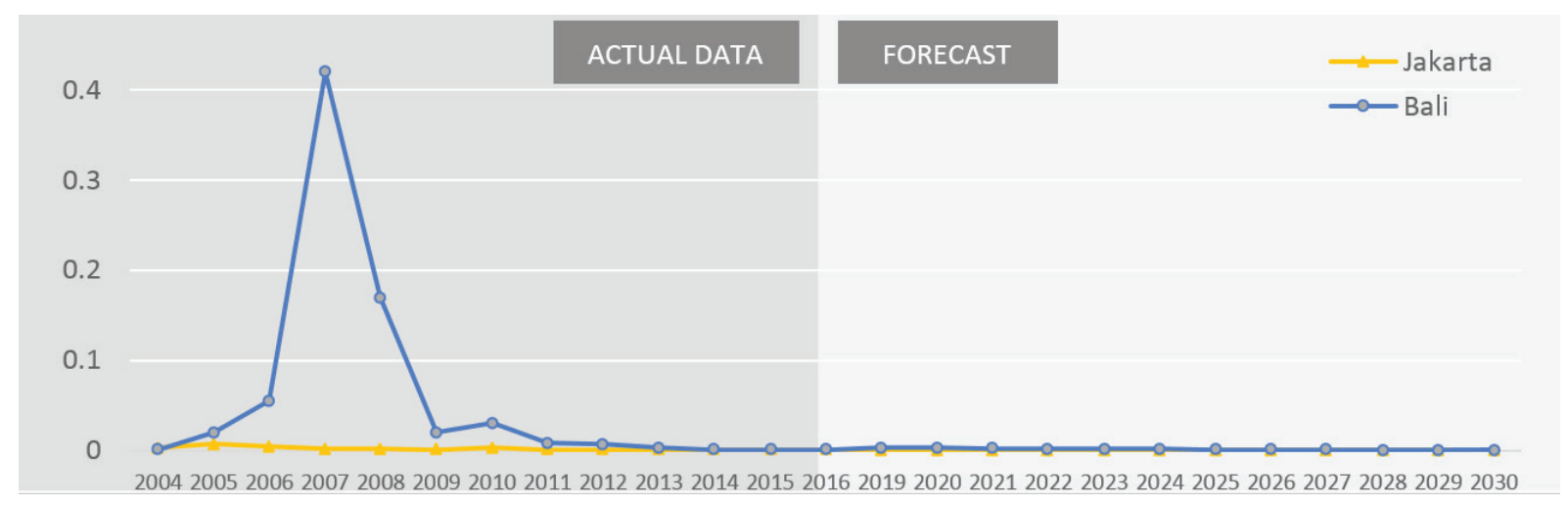

Figure 4 shows the results of the API value prediction for the first target area for malaria elimination. Based on that picture, it can be seen that since 2013, the Jakarta and Bali regions had indeed entered the malaria elimination area which was characterized by an API value close to zero. This was supported by data from the Ministry of Prevention and Control of Vector and Zoonotic Diseases of the Ministry of Health that all districts/cities in DKI Jakarta and Bali have eliminated malaria since 2016 .
Elimination of malaria could be successful in this target area because indeed, since 2004, API values in this area was small, ie less than $\mathrm{I}$. This showed that indeed the spread of malaria in this area was classified as rare. Even though this first targeted area had been eliminated from malaria, its achievements could be implemented in 20I6. These results missed the target set by the Ministry of Health which had targeted the first targeted area to be free of malaria in 2010. 
Figure 5 API Value Forecast for The Second Targeted Area

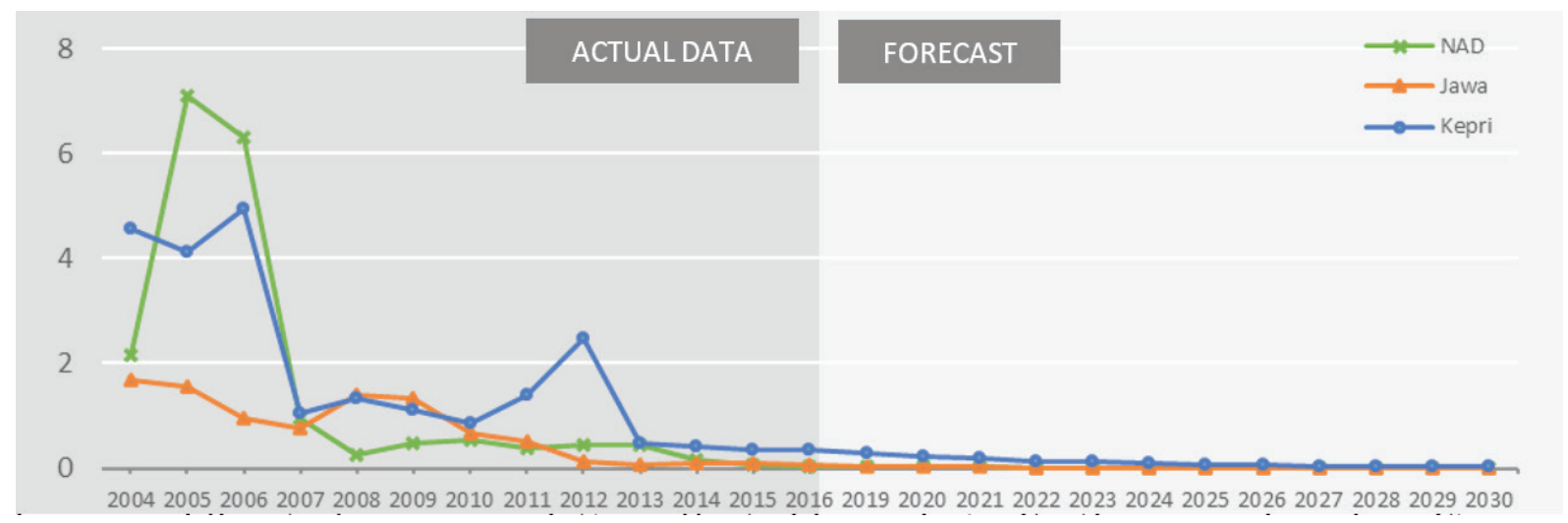

Figure 6 API Value Forecast for The Third Targeted Area

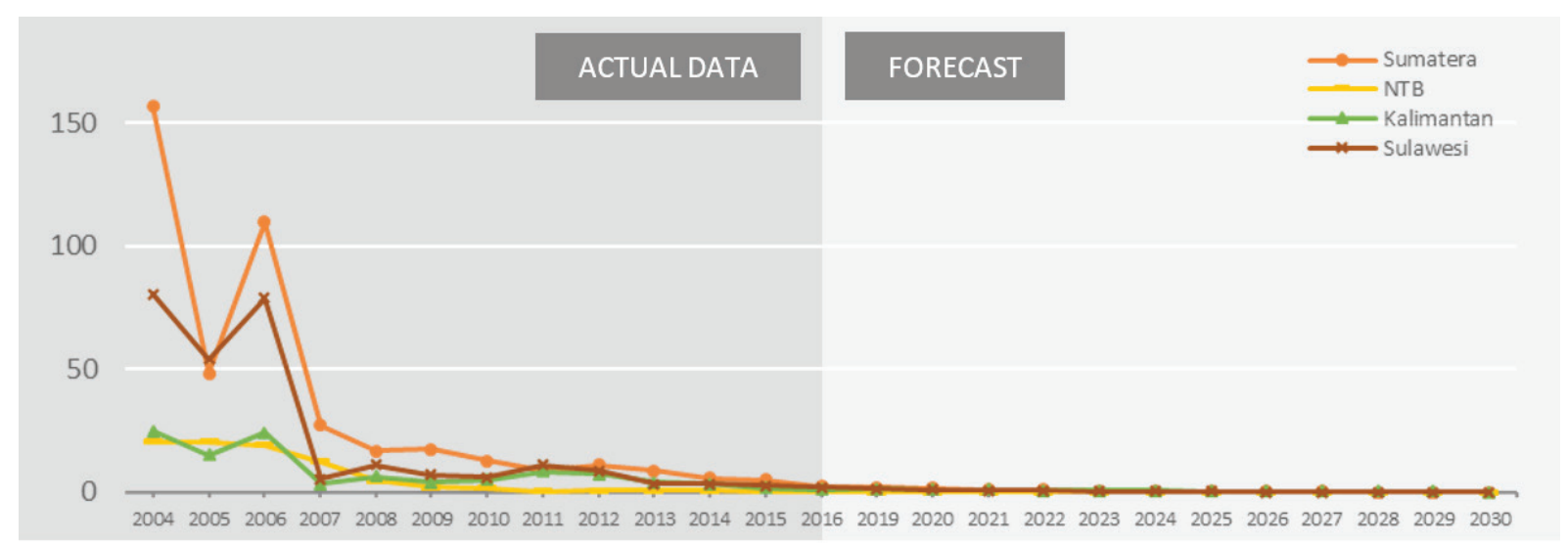

The second target area for the malaria elimination program consisted of NAD, Java and Riau Islands regions. Since 2004, this area have had a fairly low API value, which was less than 8 . It showed that the spread of malaria in this area was also rare, where there would be around 8 out of 1000 population affected by malaria. Furthermore, based on Figure 5, the API value in this area tended to be close to zero starting in 2019. This estimation was missed the target set by the Ministry of Health which had targeted this area to be free of malaria in 2015.

The third target area for the malaria elimination program consisted of Sumatera,
West Nusa Tenggara, Kalimantan and Sulawesi Island. This area was classified as an area with a high API value, which was less than I6o, which means that there will be at least I 60 out of 1000 populations infected by malaria. In this area, two islands with high API values were Sumatra and Sulawesi. However, since 20I6, this area could be said to have almost succeeded in eliminating malaria, with API values approaching zero. The forecast results in Figure 6, on the previous page, also shows that in 2022, this area would be $100 \%$ successful in eliminating malaria. It actually missed the target set by the Ministry of Health ministry which targeted this area to be free of malaria by 2020 . 
Figure 7 Figure 5 API Value Forecast for The Forth Targeted Area

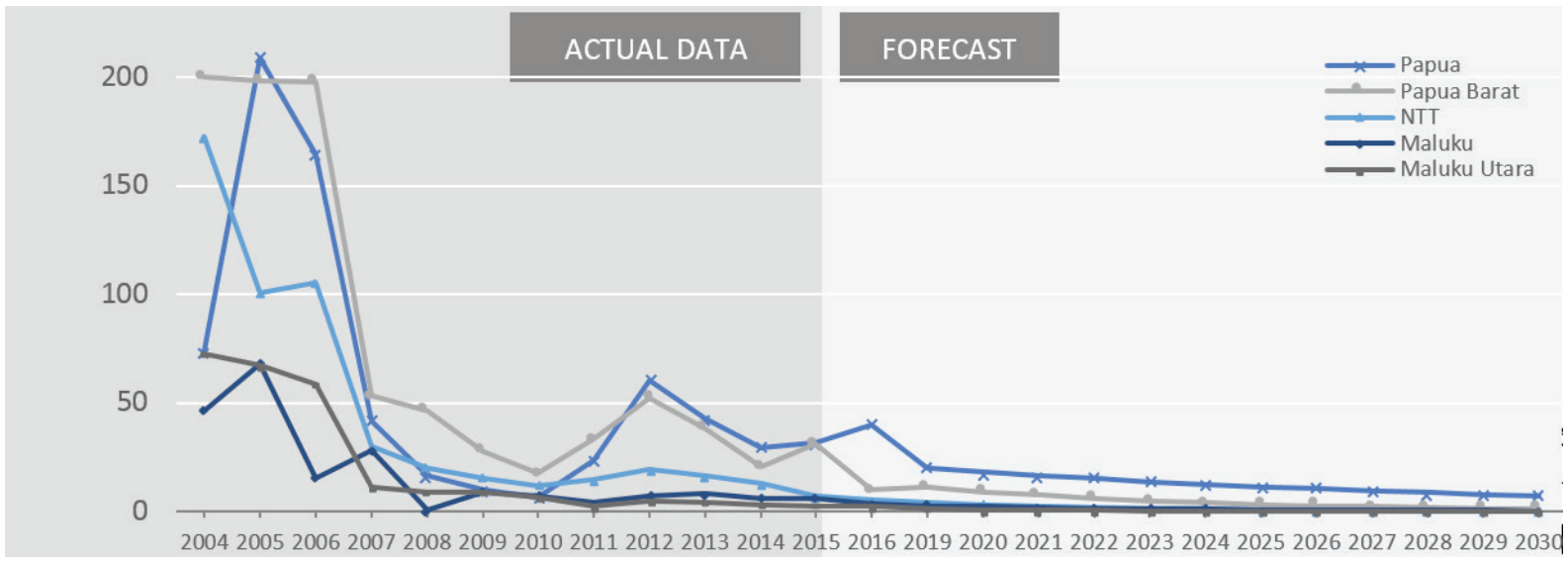

The target area of the $4^{\text {th }}$ malaria elimination program consisted of Papua, West Papua, East Nusa Tenggara, Maluku and North Maluku regions. The fourth target area was an endemic area of malaria with a high API value of around 220 , which means there will be 220 out of 1000 populations infected by malaria. The regions with the most malaria spread were Papua and West Papua. Geographical factors were one factor in the high number of malaria cases in the Eastern Indonesia Region, considering that this region was a swamp area and many mines exist. The people often carry out local mining and move around and then go undetected, causing inundation, which when the rain comes this will becomes the place of anopheles mosquitoes to breed. In this region, the most prevalent malaria disease was tropical malaria caused by palsivarum parasites and tertiary malaria caused by the faitian parasite (JPNN, 20IO).

\section{Transformation of API Value in Indonesia 202I-2030}

Based on the forecast results, the malaria elimination program in the upcoming 202I-2030 has experienced a decline near zero in API values. In other words, out of Iooo population, there were only one person who would be positive for malaria. The following is a visualization of the API values development forecast in Indonesia in the upcoming Iryears.

Figure 8. Transformation of API Value in Indonesia (a) 202I, (b) 2024, (c) 2027, (d) 2030

(a)

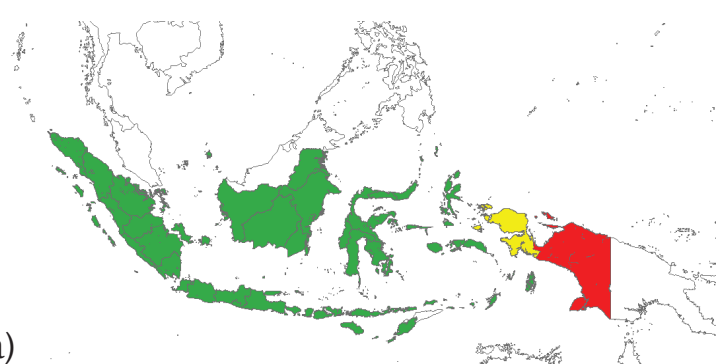

(c)

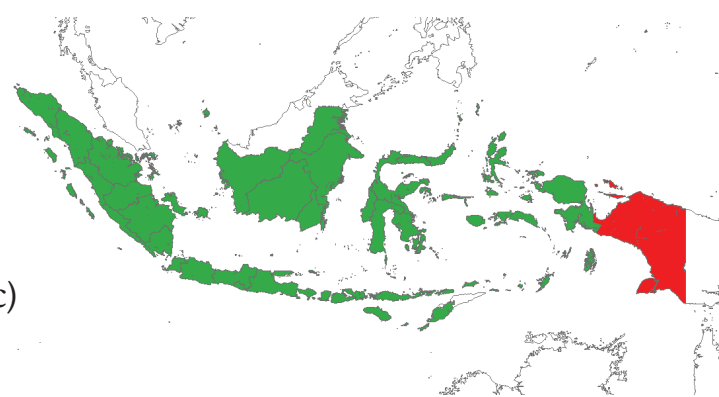

(b)

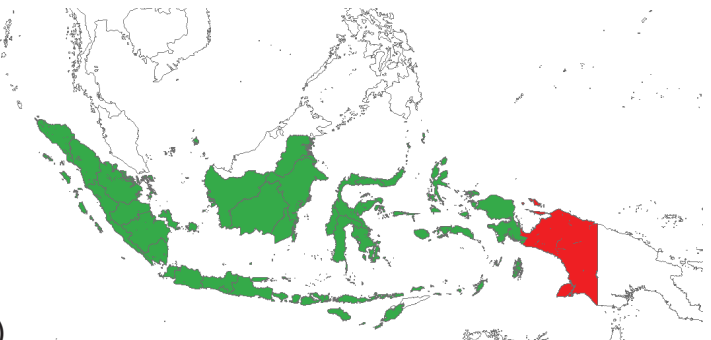

(d)

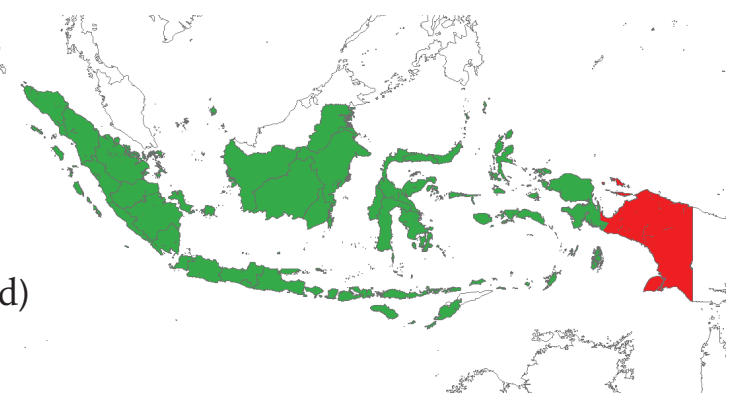


Figure 8 , on the previous page, shows the transformation of API values based on previous prediction results. From the picture, it can be seen that until the year 202I, the $\mathrm{I}^{\text {st }}, 2^{\text {nd }}$, and $3^{\text {rd }}$ targeted areas for the malaria elimination program have successfully Ioo\% eliminated from malaria. The targeted area 4 had not been completely eliminated malaria, especially the West Papua region with moderate malaria endemicity (marked by yellow color), and Papua with high malaria endemicity (marked by red images). Furthermore, in the year 2024-2030, Indonesia will be free from malaria, except for the island of Papua which has high malaria endemicity levels yet. It needs special attention from the government to monitor the malaria elimination program in the $4^{\text {th }}$ targeted area, especially in the Papua region.

Some efforts had been made by the government to eliminate malaria in these target areas, including the administration of insectiside residual spray (IRS), distribution of bed nets, chemoprophylaxis, and the use of mosquito repellent. In addition, other efforts undertaken by the government were environmental management (including spreading larvae such as tilapia and betta fish), providing special training to experts (doctors, nurses, analysts, cadres, surveillance officers, etomologists) to help do early detection to the public, and provide socialization to the community to cover excavated land, puddles or muddy places which were breeding grounds for mosquitoes. The effort to overcome malaria cases was by giving Artemisinin-based Combination Therapies (ACT) in 24 hours of fever patients. Although the government had made a lot of effort, malaria could not be completely eradicated in this area because access to health services was still lacking. Even though the patient referral system had been addressed, patients had not received the right treatment, so the number of malaria infections in this area is still high.

\section{DISCUSSIONS}

\section{The Fulfillment of Malaria Morbidity Pre- diction Under The Certain Circumstances}

This prediction would be fulfilled under Malaria
Surveillance. Malaria surveillance was needed to support three activities: early warning, outbreak management and post-outbreak management. Data collection was started from sub-primary health centres and aggregated by the upper levels. The monthly transfer of data from the primary health centres to the district health office was done by hand delivery, fax or email. The district health offices then used this data to create graphs showing trends, distribution and minimum-maximum case loads. The processing and analysing of data was conducted at primary health centre level. An increase in the number of malaria cases, which was more than twofold the number of cases during the normal period, was designated as the threshold of a malaria warning. Another important aim of such data collection was the informing of maps of malaria risk. The maps, in turn, inform the placement of the limited control resources precisely where and when they were needed. However, in 2007, Elyazar et al. showed that primary health centres did not have the sufficient capacity to analyse these data (Elyazar and Rachmat, 2004; Elyazar et al., 2007).

Effective surveillance of malaria in Indonesia required important challenges to be overcome. As already described, only I3-I6\% of estimated clinical malaria cases came with a microscopic or RDT confirmation. In other words, $84-87 \%$ of clinical malaria cases were undetected by health facilities. This leads to the under-reporting of malaria case figures given by the $\mathrm{MoH}$. The situation was also hampered by the existence of people with malaria who do not seek malaria treatment (2I-26\%) or people who treat themselves (10-31\%). Therefore, the API data reported by district health offices was unreliable. There was no correction factor of API in their reports as high proportion of clinically diagnose malaria.

Another problem was the limited coverage of malaria cases treated by private clinics, physicians and hospitals. The ongoing malaria surveillance used by Indonesia's MCP had not accommodated data generated at those sources. The Indonesian Hospital was reporting system aggregates malaria data from all hospitals in Indonesia. The system reported the number 
of malaria cases without detailing the Plasmodium. The details were kept by each hospital. To assemble, these data would therefore mean to connect with over I300 hospitals across the archipelago. There was no adjustment of API in the MCP reports to take into account the low contribution of data from clinics, physicians and hospitals.

\section{The Implications of The Result Toward The Malaria Program}

The implication of this result of morbidity prediction affected malaria control policy in Indonesia. The first was the Roll Back Malaria (RBM) campaign initiative launched by the WHO in 1998. This initiative aimed to spark efforts that would lead to halving the number of malaria deaths by 2010. In Indonesia, on 8 April 2000, the Ministry of Health, following the WHO's global RBM campaign, launched an Indonesian version called 'Gebrak Malaria' or, in English, 'Crush Malaria'. This program consisted largely of seven steps recommended for control in malaria endemic districts. These steps were (I) producing a map of endemicity and identifying foci of malaria, (2) identifying the feasibility of collaboration between communities and related government sectors, (3) developing strategic plans for malaria control, (4) obtaining support from the District Health Office and Legislative Council, (5) developing an integrated working plan for malaria control, (6) implementing the working plan and (7) monitoring and evaluating the strategy and the progress made. The 'Crush Malaria' program was supported by the following activities: (I) active and passive case finding coupled with periodic mass surveys, including a mass fever survey, a mass blood survey (MBS) and a malariometric survey (all of which require community participation at the designated village malaria post), (2) case management with effective drugs, (3) vector control and (4) surveillance. However, the new era of widespread drug resistance, the broad decline of vector control activities, the severe economic and political upheavals and the fledgling democratic government now seeking to decentralize its authority have all been a serious challenge to malaria control.
Malaria elimination activities were to be conducted in four stages. These stages included: (Stage I) The thousand Islands (Jakarta) and Bali and Batam Islands in 2oIo; (Stage 2) Java, Aceh and Riau Islands in 2015; (Stage 3) Sumatra, West Nusa Tenggara, Kalimantan and Sulawesi in 2020 and (Stage 4) Papua, West Papua, East Nusa Tenggara and Maluku Islands in 2030. To achieve the goal of elimination, the Ministry of Health had set targets. The first target was that in 2010 all health service facilities must have the capacity for malaria examination. In other words, all people diagnosed with clinical malaria must be confirmed as malaria cases by microscopy or reliable RDT. The second target was for Indonesia to enter the pre-elimination stage in the year 2020. The third target was for the whole of Indonesia to be free of malaria transmission in 2030.

Following this call for elimination, Indonesia had to start to improve the surveillance system, the malaria outbreak management system and the tools for communication, information and education. The improvement of the capacity for early detection and outbreak management was essential. A robust malaria information system must be established to store, analyse and present information as needed. Indonesia had to establish reliable migration and surveillance systems. The improvement of malaria mapping skills was very important as risk maps can be used to inform operations, to identify ongoing transmission foci or hot spots and to focus elimination efforts (Feachem and Sabot, 2008; Feachem and The Malaria Elimination Group, 2009; Feachem et al., 2009).

\section{CONCLUSION}

In forming a scenario for predicting malaria morbidity in Indonesia, the best forecasting method was a deterministic method using exponential growth with the smallest MSE value of 28,456 . Using this method, predictions of API values were obtained for each targeted area of the malaria elimination program for 2019-2030. Based on the prediction results, it could be seen that until 2030, the $\mathrm{I}^{\text {st }}, 2^{\text {nd }}$, and $3^{\text {rd }}$ targeted area will be $100 \%$ eliminated by malaria. The fourth targeted area has not yet been Ioo\% eliminated 
by malaria, especially in the Papua region.

It showed the importance of the government role to monitor the malaria elimination program in the $4^{\text {th }}$ targeted area. Achieving elimination would require advancements that fill the many gaps in understanding of this menace to the public. It falls upon contemporary malariologists to leverage all of that effort in order to improve this understanding and thereby achieve greater impacts with smarter interventions against malaria.

Control strategy must be tailored to localities, and this largely defined the difficulty of achieving gains against malaria at a national level. The instinct to consider as essential to progress the dissection and grasp of every nuance of malaria transmission across the many thousands of settings across Indonesia should be resisted by malaria experts working the problem. This would perhaps trend towards hopelessness and abandonment of effort. Research effort was desperately needed to better inform malaria control and elimination strategies, regardless of who carries it out: the Ministry of Health, Ministry of Science \& Technology, local governments, universities, NGOs, and, ideally, informed and determined local citizens.

\section{REFERENCES}

Abidin, Z., \& Hernawan, D. (2010). Prevalensi Malaria Klinis dan Positif Plasmodium spp. Berdasarkan Mass Blood Survey di Kabupaten Rokan Hilir Provinsi Riau. Jurnal Aspirator Vol.2 No.I Tahun 2010 : 84-9I.

Chin, J. (2006). Manual Pemberantasan Penyakit Menular. Jakarta : CV Infomedia.

Departemen Kesehatan RI. (I999). Epidemiologi Penyakit Malaria. Direktorat Jenderal Pemberantasan Penyakit Menular dan Penyehatan Lingkungan Pemukiman. Jakarta: Departemen Kesehatan RI.

Departemen Kesehatan RI. (2006). Pedoman Surveilans Malaria. Ditjen PP dan PL, Dit. Pengendalian Penyakit Bersumber Binatang. Jakarta : Departemen Kesehatan RI.

DJaja, S., Wiryawan, Y., \& Maisya, B. (2009). Tren Penyakit Penyebab Kematian Bayi dan Anak Balita di Indonesia Dalam Periode Tahun 1992-2007. Jurnal Ekologi Kesehatan Vol.8, No.4, Desember 2009 : IIOO-IIO7.
Elyazar, I.R.F., Rachmat, A., Tobing, C., \& Rodayah, H., 2007. Assessment of Malaria Management Information System in Nanggroe Aceh Darussalam Province 2006. Sub-Direktorat Pengendalian Malaria Direktorat Jendral Pengendalian Penyakit and Penyehatan Lingkungan and US Namru 2, Jakarta, Indonesia, I4 pp.

Elyazar, I.R.F., Hay, S.I., \& Baird, J.K. (20II). Malaria Distribution, Prevalence, Drug Resistance and Control in Indonesia. Advances in Parasitology, Volume 74, DOI: Io.roi6/ B978-0-I2-385897-9.00002-I

Feachem, R.G.A., Phillips, A.A., \& Target, G.A., (2009). Shrinking the Malaria Map: A Prospectus on Malaria Elimination. The Global Health Group, Global Health Sciences, University of California, California.

Firdausi, K,, Saudi, Y., \& Sutikno, T. (2007). Deteksi API Real-time Dengan Metode Thresholding Rerata RGB. Jurnal Telkomnika, Vol.5, No.2, Agustus 2017 : I27-I32.

Friaraiyatini, F., Keman, S., \& Yudahstuti, R. (2006). Pengaruh Lingkungan Dan Perilaku Masyarakat Terhadap Kejadian Malaria di Kabupaten Barito Selatan. Jurnal Kesehatan Lingkungan Vol 2. No. 2.

Gandahusada, S. (1990). Fight Againts Malaria In Indonesia. The National Institute of Health Research and Development, Ministry of Health Republic Indonesia.

Hidajah, A.C., Notobroto, H.B., Yudhistira, R., \& Hargono, A. (2006). Dinamika Penularan Malaria di Daerah Perbatasan. Surabaya : Penerbit Universitas Airlangga.

JPNN, (2010). 2030 Target Eliminasi Malaria. Available in https://www.jpnn.com/news/2030-targeteliminasi-malaria/.

Mirontoneg, A.R. (20I6). Analisis Faktor-faktor yang Berhubungan Dengan Kejadian Malaria Pada Anak di Wilayah Kerja PKM Tona Kecamatan Tahuna Kabupaten Sangihe. Manado: Penerbit Universitas Sam Ratulangi.

Nofianti, T. (2014). Kejadian Malaria dan Status Gizi Balita di Kabupaten Manokwari Provinsi Papua Barat. Jurnal Gizi Klinik Indonesia Vol Io No.4 April 2014 : I80-I90.

Rachmadhani, D., \& Widayani, P. (20I4). Pemodelan Prediksi Kerawanan Penyakit Malaria Menggunakan Metode Ordinary Least Square (OL) di Sebagian Kabupaten Kulon Progo. Yogyakarta : Penerbit Universitas Gadja Mada.

Rejeki, D.W.S, Sari, R.A, \& Nurhayati, N. (2014). Annual Parasite Incidence Malaria di Kabupaten Banyumas. Jurnal Kesehatan Masyarakat Nasional Vol 9, No 2, November 20I4 : 137-I43. 
Santoso, B. (2010). Prevalensi Malaria Klinis dan Positif Plasmodium spp. Berdasarkan Mass Blood Survey di Kabupaten Maluku Tenggara Barat. Jurnal Aspirator Vol.2 No.I Tahun 2010 : 04-IO.

Setya, F., et al. (I997). Prevalensi Malaria Pada Anak di Beberapa Sekolah Dasar Kecamatan Padang Cermin Lampung. Majalah Kesehatan Masyarakat Indonesia.

Sopi, I. I.P.B, \& Patanduk, Y. (2015). Malaria Pada Anak di Bawah Umur Lima Tahun. Jurnal Vektor Penyakit Loka Litbang P2B2 Waikububak, Nusa Tenggara Timur : 65-7I.

Sutarto, C. E. (20I7). Faktor Lingkungan, Perilaku dan Penyakit Malaria. Jurnal Agromed Unila Vol.4, No.I, Juni 2017 : I73-I84.

Tarmidzi, M., Tjokrosonto, S., \& Sudargo, T. (2007). Hubungan Antara Kejadian Malaria Dengan Status Gizi Balita. Jurnal Berita Kedokteran Masyarakat Vol.23 No.I, Maret 2007 : 4I-46.
Tazkiah, M., Wahyuni, C.U., \& Martini, S. (2013). Determinan Epidemologi Kejadian BBLR Pada Daerah Endemis Malaria di Kabupaten Banjar Provinsi Kalimantan Selatan. Jurnal Berkala Epidemiologi Vol.I, No.2, September 20I3 : 266-276.

Wardah, S., \& Iskandar. (2016). Analisis Penjualan Produk Keripik Pisang Kemasan Bungkus (Studi Kasus : Home Industry Arawana Food Tembilahan). Jurnal Teknik Industri Vol.II, No.3, September 2016 : I35-I42.

WHO. (I997). Malaria In The South-East Asia Region. New Delhi. 